\title{
WAIVER OF STATUTORY RIGHTS AND THE JUDICATURE ACT
}

\author{
E. A. D. McCualg, Q.C. and D. C. McDonalo*
}

"As a general rule, any person can enter into a binding contract to waive the benefits conferred upon him by an act of Parliament, or, as it is said, can contract himself out of the Act, unless it can be shown that such an agreement is in the circumstances of the particular case contrary to public policy." The two branches of this rule have been otherwise stated as follows:

(1) If the object of the statute is not one of general policy or if the thing which is being done will benefit only a particular person or class of persons, then the conditions prescribed by the statute are not considtred as being indispensable. Quilibet protest renunciare juri pro se introducto. ${ }^{2}$

(2) Where the statute lays down a rule of public policy, it is not competent for a person intended to be benefited thereby to contract himself out of, or to waive the provisions.

The application of the general rule to the interpretation of specific statutes in the past has left no sure guide as to when a Court will decide that there may be waiver or when it may decide that there may not be waiver of a statutory provision. ${ }^{3}$ A few of the leading English cases may be noted.

In Griffiths v. The Earl of Dudley a County Court Judge had held that the deceased could not contract himself out of the provisions of the Employers' Liability Act, 1880, so as to bind his widow in case of death resulting from injuries received in his employment, and that any agreement to that effect was void as being against public policy. This judgment was reversed on appeal, when Field, J., said: ${ }^{s}$

"I am unable to concur in the view taken by the learned county court judge of these facts and of the Statute. He held that the contract was against public policy. It is at least doubtful whether, where a contract is said to be void as against public policy, some public policy which affects all society is not meant. Here the interest of the employee only would be affected. It is said that the intention of the legislature to protect workmen against imprudent bargains will be frustrated if contracts like this one are allowed to stand. I should say that workmen as a rule were perfectly competent to make reasonable bargains for themselves. At all events, I think the present one is quite consistent with public policy ...

"In all the cases referred to in argument, in which the legislature has intended to enact that a person shall not be allowed to contract himself out of an Act of Parliament, very express words have been used. As a general rule entire freedom of contrace has been preserved; it has only been interfered with in order to obviate great public injustice."

Cave, J. said: ${ }^{\circ}$

"I am of the same opinion. The main question is whecher or not a workman can contract himself or his representatives out of the benefits of the Employers' Liability Act. The plaintiff's husband did so contract himself; it is said that the contract was against public

* of McCuaig, McCuaig, Desrochers, Beckingham \& McDonald, Edmonton, Alberta.

'Halbury's Laws of England, 3rd (Simonds) ed., vol. 8, p. 143.

2"Any one may, at his pleasure, renounce the benefit of a stipulation or other right introduced entirely in his own favoure." Broom's legal Maxims, 8th ed., p. 545.

sFor a discussion of cases on contracting out of the Intestate Succession Act, the Family

Relief Act, and the Dower Act, see Morris Shumiatcher, (1938-39) 3 Alberta L. Q. 240.

(1882) 9 Q.B.D. 357.

slbid., at pp. 363-364.

BIbid., at pp. 364.365. 
policy. No authority has been cited in support of that proposition, and I can see no reason why such a contract should be against public policy. I should not hold it to be so, and thus interfere with freedom of contract, unless the case were clearly broughe within the principle of the decisions as to the contracts which are against public policy."

An important decision of the Privy Council is Equitable Life Assurance Society of the United States v. Reed. The problem in this case turned on the meaning and effect of section 64 of the New Zealand Insurance Act of 1908 which reads:

"No policy shall become void by non-payment of premium so long as the premiums and interest in arrear are not in excess of the surrender value as declared by the company issuing the same in the answer of such company given to the tenth question of the seventh schedule hereto."

Section 64 is the first of a series of sections headed "Protection of Policies." The other sections, which end with section 66 , are concerned with the protection of policies from the effects of bankruptcy and securing that the proceeds of a policy at death shall pass to the representatives of the deceased. Their Lordships held that this was a section intended to lay down a rule of public policy, and that it is impossible for either an assured or an assurer to contract himself out of it or to waive its effect. They went on to state that in all cases where something not ipsa natura unlawful is prohibited by Statute the words of prohibition must be taken as they stand; they must not be amplified in order to meet a supposed evil or restricted in order to protect a natural freedom. In other words, the evil that was to be checked can be considered only so far as is necessary for the interpretation of the words, but must not be used as an independent determination of the scope of the remedy. Their Lordships added that the prohibition in s. 64 is universal, that it is directed equally against a special stipulation to that effect and against the common law result in mutual contracts falling within the section when one party fails to perform his part of the bargain or when the liability of one party is expressed to be conditional on the other party performing his part of the bargain.

In Salford Guardians v. Dewhurst, ${ }^{8}$ there are important dicta. A compulsory scheme for providing pensions for poor law officers and servants was established by the Poor Law Officers Superannuation Act, 1896. Obligatory pensions were payable by the Guardians and obligatory contributions by the officers and servants. The pensions were expressly made inalienable, but there was no express provision against contracting out. It was held by four of the Law Lords, with one dissenting, that upon the construction of the Act it was not open either to the guardians or to their officers or servants to contract themselves out of the statutory obligations and rights respectively imposed or conferred upon them by the Act. Viscount Cave, L. C. said:

"But there is another way of putting the questeon, and that is, can the guardians by any action exclude the application of this statute to any of their officers? If they can, then the guardians have a ready way of relieving themselves from the burden imposed by the statute. In that case they can either before appointing a particular officer or servant, or before con. senting to an increase of his remuneration, require him to agree with them that this particular statute shall not apply; indeed, they could make it their general practice before appointing any officer to make it a condition that he shall not been entitled to pension.

T[1914] A.C. 587.

8[1926] A.C. 619.

OIbid., at p. 625. 
I do not doubt that, if a board adopted that practice, they would find persons who would accept emplopment on those terms and would enter into an agreement that the Act shall not apply. If that is so, then it is in the option of boards of guardians to determine whether or not this statute shall apply, and they can (as one of the learned Lords Justices said) make the statute a dead letter. I cannot think that was the intention of Parliament. It rather appears to me that by using the imperative terms to which I have referred, Parliament has indicated an intention that the Act shall apply, notwithstanding any agreement to the contrary, to every board of guardians and to every officer or servant of such a board."

\section{Lord Shaw of Dunfermline said: ${ }^{10}$}

"My Lords, the argument against that view, which has been presented with elaboration and force, is that, notwithstanding all these provisions, it is still possible to contract out of the whole concern. It is, in my opinion, quite impossible, in view of that statute, that guardians can relieve themselves of all their statutory liability by appointing a class of pensionless servants, when Parliament in its wisdom has declared that this class of public servant shall be pensionable. Such an idea is, as I view it, contradictory both of the spirit and of the letter of this Superannuation Act. The whole scheme and scale and framework of the allowances and the contributions is made upon the footing that it is a comprehensive scheme, and to allow individual exceptions to be made at the will of the guardians would be contradictory to the Act as a whole, and might completely wreck the whole scheme, which must fundamentally rest upon some actuarial basis."

\section{A contrary view was taken by Lord Sumner: ${ }^{11}$}

"I do not think it is correct to say that the mere use of the words 'shall be entitled' is enough to import this unexpected and curious result, and I do not think that any public policy has been suggested that would show this particular result to be what the Legislature contemplated. The contrary assumption-namely, that the Legislature did not couch the right to contract for a waiver or abandonment of benefits that might otherwise have been claimed, is neither contrary to public policy nor surprising in itself."

An Alberta example of the problem of deciding whether or not the benefits of a statute may be waived is found in Marchyshyn v. Fane Auto Works Ltd. ${ }^{12}$ There the Alberta Appellate Division considered whether the provisions of the Alberta Evidence $A c t^{13}$ relating to the number of expert witnesses which may be called by a party, can be waived by a litigant. In delivering the judgment of the Court, McGillivray, J. A., said: ${ }^{14}$

"If the statute in question be one of public policy it clearly cannot be waived by a private individual nor can the Judge and all Counsel agree to ignore a statucory prohibition necessary for the common welfare. On the other hand, if the stature be one regulating procedure and practice in the Civil Courts which does not go to jurisdiction it may be waived by those for whose protection and advantage the statute was intended."

In this article it is intended to consider the extent to which the provisions of section 34 (17) and (18) of the Judicature Act (Alberta) ${ }^{13}$ may be waived. In the Province of Alberta this is a problem which frequently confronts conveyancers and overshadows in practical importance all other questions of the extent to which there may be waiver of statutory rights.

During the past forty years the Legislative Assembly of Alberta has, from time to time, legislated to eliminate most, if not all, of the rights of recovery which may be exercised at common law by a mortgagee or vendor of land against the mortgagor or purchaser. The effect of two world wars and recurring depressions seriously affected the economy of the Province, and the

1016id., at p. 628 .

11Ibid., at p. 633.

12[1932] 3 W.W.R. 232.

13Then R.S.A. 1922, c. 87, s. 10; now R.S.A. 1955, c. 102, s. 11; amended 1958, c. 18, s. 2. 14lbid., at pp. 238-239.

15R.S.A. 1955, c. 164. 
people's representatives in the Legislative Assembly felt it necessary to curtail these rights. The nature of the statutory provisions which preceded those now in force will become evident in the discussion of cases which is to follow. The present subsections as follows:

(17) In an action brought upon a mortgaga of land whecher legal or equitable, or upon an agreement for the sale of land, the right of the mortgagee or vendor thereunder is restricted to the land to which the mortgage or agreement relates and to foreclosure of the mortgage or cancellation of the agreement for sale, as the case may be, and no action lies;

(a) on a covenant for payment contained in any such mortgage or agreement for sale,

(b) upon any covenant, whether express or implied, by or on the part of a person to whom the land comprised in the mortgage or agreement for sale has been trans. ferred or assigned subject to such mortgage or agreement for the payment of the principal money or purchase money payable under any such mortgage or agreement or part thereof, as the case may be, or,

(c) for damages based upon the sale or forfeiture for taxes of land included in the mortgage or agreement for sale, whether or not the sale or forfeiture was due to, or the result of, the defaule of the mortgagor or purchaser of the land or of the transferee or assignee from the mortgagor or purchaser.

(18) In an action brought upon a mortgage of land or upon an agreement for sale of land the order nisi in the case of a mortgage, or the order for specific performanct in the case of an agreement for sale, made in the action, shall direct that if the defendant fails to comply with the terms of the order, the land that is subject to the mortgage or agreement for sale is to be offered for sale at such time and place, in such manner, after such advertisement of sale, and at such price as to a Judge seems proper, and if the land that is subject to the mortgage or agreement for sale is not sold at the time and place so appointed, a Judge may either order the land to be again offered for sale or may make a vesting order in the case of a mortgage or an order of cancellation in the case of an agreement for sale, and upon the making of any such vesting order or cancellation order, every right of the mortgagee or vendor for the recovery of any money whatsoever under and by vircue of the mortgage or agreement for sale in either case ceases and determines.

It has long been established that an action brought on the personal covenant given by a mortgagor or a purchaser under an Agreement for Sale is "an action brought upon a mortgage of land ... or upon an Agreement for Sale of Land" within the terms of the Judicature Act. The leading authority for this proposition is MacDonald v.Clarkson, ${ }^{16}$ a decision of the Appellate Division of the Supreme Court of Alberta. The defendant Clarkson, being indebted to the plaintiff, had assigned to the plaintiff a mortgage, of which he was the mortgagee, containing a covenant by the mortgagor for payment. The assignment contained a covenant by the defendant "that in case the said mortgagor makes default in payment of any sums of money as shall at any time hereafter become due and payable for interest and principal or otherwise, under and by virtue of the said mortgage, that he will pay or cause the said sum so in default to be paid." Default having arisen under the mortgage, the plaintiff brought an action against the mortgagor and Clarkson claiming a personal judgment upon the mortgagor's covenant, a personal judgment against Clarkson by virtue of his covenant in the assignment, and sale or foreclosure of the mortgaged premises. At that time the Judicature Act provided ${ }^{17}$ that the amount judged to be paid in any action brought upon a mortgage of land should be realized in the first instance pro tanto by a sale of the land mortgaged. Upon the application for judgment, the Master in Chambers held that the plaintiff was

10[1923] 3 W.W.R. 690.

17R.S.A. 1922, c. 72, s. 37 (0) (i). 
entitled to judgment against the defendants and that the amount so ordered to be paid should be realized in the first instance pro tanto by a sale of the mortgaged land, thus precluding the enforcement of the personal judgment until after the sale. On appeal, the trial judge removed the stay of execution against the defendant Clarkson, holding that the action as against Clarkson was not an action upon a mortgage of land. Subsequently, the Appellate Division held that this was an action brought upon a mortgage of land, and allowed the appeal. Clarke, J. A., said: ${ }^{18}$

"I think there can be little doubt that the substance of the action is the recovery of the mortgage debt, it is immaterial how or by whom paid, if paid in any way the action is at an end. The personal liability of the mortgagor arises from his covenant to pay contained in the mortgage and that of the appellant (defendant Clarkson) from his covenant to pay contained in the transfer, but in either case it is the mortgage debt which is to be paid. The plaintiff could not succeed witheut establishing the mortgage and the amount owing upon it. The covenants are the means of fastening liability for the mortgaged debt upon the coven. antor. Certainly an action against the mortgagor alone upon the covenant in a mortgage under The Land Titles Act would be an action brought upon a mortgage and if the covenants of the Appellant were contained in the mortgage it would be an action upon the mortgage. What difference does it make that the covenant is contained in another instrument? It is still a covenant to pay the mortgage debt."

It will be noted that the action against Clarkson upon his covenant was held to be an action brought upon a mortgage of land even though Clarkson was not the mortgagor. In the more usual type of case, at the time a mortgage or an Agreement for Sale is entered into, a personal covenant is taken from a stranger to the mortgage or Agreement for Sale, such as a son or father of the mortgagor or some other party financially responsible. If the mortgagee sues such person on his personal covenant, it is clear that the action is not initially "an action brought upon a mortgage of land." However, MacDonald v. Clarkson is authority for the Courts' regarding the person giving the covenant as a surety, and the Courts recognize that the "surety" can compel the joinder of the mortgagor as a party to the action. Once this is done, the action is transformed into "an action brought upon a mortgage of land." Clarke, J. A., says: ${ }^{10}$

"Even wete the action against the appellant alone (Clarkson), and for that reason could be said not to be an action upon the mortgage, the appellant being only a surety could compel the plaintiff to make it a mortgage action by asking that the mortgagor be joined."

With this background, it is now possible to examine the cases in which the Courts have considered the extent to which the provisions of the Judicature Act made be waived. In Crang v.Rutherford,,$^{20}$ the mortgagor and mortgagee entered into a renewal agreement whereby the time for payment of the mortgage monies and interest was extended and the rate of interest reduced. This renewal agreement contained the following clause:

"And in further consideration of the extension hereinbefore granted, the said parties of the second part jointly and severally for themselves, their and each of their heirs, executors, administrators and assigns hereby guarantee the said party of the first part payment of the said interest on the dates and in the manner when the same becomes due as hereinbeforc stipulaced and agrees that the party of the firse part shall have the right to recover same as for a debt owing witheut first applying for foreclosure and sale of the said lands; it being understood that this clause shall operate as a collateral guarantee by the parties of the second part for the payment of the said interest and that any default in payment of such

18[1923) 3 W.W.R. 690 , at P. 692.

10Ibid., at p. 693.

20[1936] 2 W.W.R. 205. 
shall entitle the party of the first part to personal judgment for the amount so in default, reserving at all times to the party of the first part the additional rights to foreclosure and sale."

The section of the Judicature Act in force in 1946 was that section already discussed in connection with MacDonald v. Clarkson, namely, that requiring that the amount adjudged to be paid in a mortgage action should be realized in the first instance pro tanto by a sale of the land mortgaged.

Ford, J., held that the section of the Judicature Act was procedural and temedial only, and that the clause in the renewal agreement effected a waiver of the section. He said: ${ }^{21}$

"Then it is argued that the clause in the renewal agreement relied upon amounts to a waiver of the remedial provision of the section of the Judicature Act in question; that that clause in the agreement amounts to a consent to the plaintiff obtaining judgment in the form he now asks; and, aleernatively that the defendants are estopped from denying the plaintiff's right to issue execution for the interest, payment of which was 'guaranteed', without sale of the land, and furcher alternatively that the execution of the renewal agreement is good ground for the Court so otherwise ordering."

"The provision of the Judicature Act is in my opinion a procedural and remedial one for the benefit of mostgagors who may waive it. Any question of public policy involved is not such as to prevent it being waived by the persons for whose benefit it was passed. No public right is in question."

In 1939, the Alberta Legislature amended the Judicature Act by adding provisions identical in effect with those now contained in section 34 (17) and (18)..$^{22}$

The first case decided after the amendment was Commercial Life Assurance Co. of Canada v. Debenham. ${ }^{23}$ In this case the Alberta Appellate Division considered the effect of the amendment to the Judicature Act upon the provisions of the Farmers' Creditors Arrangement Act, 1934. ${ }^{24}$ Under the latter Act, a farmer could make a proposal to a Board established under the Act for a composition, extension of time or scheme of arrangement with his creditors. Any such proposal could provide for "a compromise or an extension of time or a scheme of arrangement ... in relation to a debt owing to a person who has acquired ... immovable property subject to a right of redemption." The Commercial Life Assurance $C_{0}$. of Canada commenced an action for specific performance against the purchaser, Debenham, who then filed a proposal under the Farmers' Creditors Arrangement Act. The purchaser applied for a stay of proceedings in the specific performance action on the ground that he had filed such a proposal. Counsel for the vendor company contended that by reason of the fact that the amendment to the Judicature Act provided that no action should lit on any covenant for payment contained in any agreement for the sale of land, there was no "debt" outstanding, that therefore Mrs. Debenham was not a "debtor" of the vendor company, and therefore that the provisions of the Farmers' Creditors Arrangement Act, 1934, did not apply to the agreement in question. However, Ford J. A., delivering the judgment of the Appellate Division, held that "the fact that it is provided that no action shall lie on the covenant does not extinguish the debt. It merely bars the remedy

\footnotetext{
s1lbid., at pp. 208.209.

22Statutes (Alberta), 1939, e. 85, 9. 2.

23[1940] 3 W.W.R. 592.

24Statutes (Canada), 1934, c. 53.
} 
by way of personal judgment on the covenant.":s Therefore, the amendment to the Judicature Act did not prevent the purchaser from being a "debtor" of the vendor within the meaning of the F.C.A. Act, 1934.

The amendment made to the Judicature Act in 1939 having been carried forward into the Revised Statutes of Alberta, 1942 and 1955, the Legislature must be taken ${ }^{20}$ to have approved of the judgment in Commercial Life Assurance Co. of Canada v.Debenham, which held that the provisions now contained in section 34 (17) (18) of the Judicature Act have a procedural rather than substantive effect.

In Martin v. Strange and Stocks Co-operative Credit Society ${ }^{27}$ Martin was execution creditor of Strange and seized certain goods of the debtor. Notice of Objection to the seizure was filed by Stocks Co-operative Credit Society, which claimed that it held a chattel mortgage covering certain goods under seizure and that its mortgage had priority over the execution. The Credit Society was the vendor under an agreement for sale of land in which Strange was named as purchaser. The chattel mortgage was expressed to be given and taken as collateral security to the agreement for sale. Before the Appellate Division it was contended on behalf of Martin, the execution creditor, that the effect of the provisions of the Judicature Act was to forbid the giving effect in any way to the personal covenant in an agreement for sale of land and that, in making the claim to the goods under seizure, the Credit Society was actively setting up the chattel mortgage as a means of obtaining payment of the monies owing under the land contract, which, it was argued, was forbidden by the Act. The Appellate Division, in a judgment delivered by Ford J. A., had no difficulty in disposing of this contention, and held that, whatever the effect of the provisions of The Judicature Act, they did not render invalid such a chattel mortgage given as collateral security to an agreement for sale of land. Therefore, so long as the vendor under an agreement for sale, or the mortgagee under a mortgage has not resorted to the land, the debt represented by the collateral security exists and in this case had priority over the execution. It is the obiter dicta in the judgment which are important for our purposes. Ford J. A. said: ${ }^{28}$

"Counsel for the respondent (Martin) does not contend that the provisions of the Judicature Act are passed for the public benefit or that they express a public policy which does not permit of their benefits being waived. In this I agree and I think it follows that in the present instance it is not open to the respondent, che execution creditor, to invoke the provisions referred to. See Mutual Life Assurance Company v. Levitt and Marks"9 and Crang v. Rutherford.

"I refrain entizely from discussing or expressing any opinion upon the effect of the televant provisions on the rights of a vendor in respect of any security collateral to an agree-

${ }^{25}[1940] 3$ W.W.R. 592, at pp. 587-598.

"See Fagnan v. Ure et al, (1958) S.C.R. 377, (1958) 13 D.L.R. (2d) 273, at p. 382 S.C.R. 277 D.L.R., per Cartwright J., citing Ex p. Campbell, (1870), L.R. 5, Ch 703 at p. 706 , where Sir W. M. James L. J. said: "Where once certain words in an Act of Parliament have received a judicial construction in one of the Superior Courts, and the legislature has repeated them without any altecation in a subsequent atatute, I conceive that the legislature must be taken to have used them according to the meaning which a Court of competent jurisdiction has given to them." This rule, as Cartwright, J., points out, has not been modified by statute in Alberta.

$27[1943] 2$ W.W.R. 123.

asibid., at p. 126.

20[1931] 1 W.W.R. 530. 
ment for sale of land. Having regard to the way this highly important question is now raised I think it inadvisable to do more than say that, whatever is the proper view as to their effect, they are provisions passed for the benefit alone of the mortgagors and the purchasers of land."

The leading case is British American Oil Company Limited v. Ferguson \& Ferguson. ${ }^{30}$ The trial judge, Egbert, J., held that two mortgagors could be sued personally on the personal covenants which they had given in the form of bonds to the mortgagee oil company. Egbert, J, held that the terms of the bond constituted a contracting out of the provisions of the Judicature Act and an implied waiver of the protection given by the Judicature Act. On appeal, the Appellate Division held by a majority of three to two that the trial judge's decision was wrong. The majority held that, assuming there can be waiver of the protection of the Judicature Act, the plaintiff oil company had not proved that the defendants had waived that protection.

The judgment of W. A. Macdonald, J.A., does not discuss whether there may be waiver of the protection of the provisions of the Judicature Act. He assumed that there may be such waiver, but held that the plaintiff had not proved that there had been waiver in fact. In the other judgment given by a member of the majotity of the Court, Clinton J. Ford, J.A., as he then was, said: ${ }^{31}$

"The trial judge held that . .. by executing the bond sued upon, the defendanes contracted themselves out of and impliedly waived the provisions of the Act.

"Assuming that they could do so, as I think I must in view of previous decisions of this

Division, which appear in cases cited by the trial judge, the question becomes one of whether they intended to, or did so effectually. It is quite clear to me on the facts that the defendants did not have any such intention; but, nevertheless, if the documents signed by them on a true interpretation effect such, they would be bound thereby."

Thus Clinton J. Ford, J.A., was of opinion that, whatever the intention of the defendants, if the documents purported to waive the protection of the provisions of the Judicature Act, the defendants were bound by such waiver. However, he reached the same result as W. A. Macdonald, J.A., namely, that the plaintiffs failed in their action, by looking at the bonds and finding that the bonds required the mortgagee to proceed first against the land, which they had not done, and only then sue for any deficiency as for a debt.

The dissenting judgment was given by Frank Ford, J.A., who agreed with the trial judge that the mortgagors, by executing the bond sued upon, contracted themselves out of and impliedly waived the benefit of the statutory provisions. However, this view was not essential to his judgment, as he held in any event, also in agreement with the trial judge (but contrary to the view of the majority of the Appellate Division) that "it is not necessary for the plaintiff ... to rely upon a 'contracting out' or 'implied waiver' of these statutory provisions, for the reason that the transaction which culminated in the bond and the agreement therein referred to, is not one to which the prohibited provisions apply."32 That is, he held, contrary to the prevailing view, that the action brought upon the bond was not "an action upon an agreement for the sale of land", so as to bring it within s. 34 (17).

${ }^{30}(1951) \perp$ W.W.R. (N.S.) 103.

B1 lbid,, at p. 113.

s2lbid., at p. 107. 
The dictum of Ford, J.A., in Crang v. Rutherford, the reference by Clinton J. Ford J.A., in British American Oil v. Ferguson, to other decisions of the Appellate Division, and the tacit assumption of W. A. Macdonald J.A., all give strong support to the view that the protection given by the Judicature Act to mortgagees and vendors under agreements for sale may be "contracted out of" or "impliedly waived". To support a contrary view it may be argued that the opinions of the judges in Martin v. Strange and British American Oil v. Ferguson were unduly influenced by the earlier decisions, which were, after all, based on legislation of a different character from that found since 1939 in the present section 34 (17) and (18) of The Judicature Act. However, whatever the validity of these two decisions on their merits, in all probability they would be followed in future cases, at least in both Divisions of the Supreme Court of Alberta.

How, then, may waiver of the statutory provisions be effected? Some guidance may be found in the two majority judgments in British American Oil v. Ferguson, although each of the judgments follows a different approach. W. A. Macdonald J.A., said: ${ }^{112}$

"It is argued the defendants waived their rights under this Act. Waiver is a voluntary and intentional relinquishment of a known existing legal right, whether conferred by contract or by law. To establish waiver it must be shown that the person waiving his rights had full knowledge of their eristence and their nature. The burden of proving knowledge on the part of the person charged with the waiver is upon the party relying on it."

In that case, W. A. Macdonald, J.A., held that the evidence did not show that the mortgagors, when they entered into the arrangement whereby they gave a personal bond, had knowledge of their rights or the nature thereof.

"On the contrary, it is a fair inference from the evidence that they had no correct understanding of the situation and never intended to relinquish any right which The Judicature Act conferred."

From this it would appear that a mortgagee relying upon waiver is in the position of having to prove quite clearly that the covenantor, before executing a document in which he purports to waive his rights, fully realized the nature of the protection given him by the Judicature Act. In the usual case, this might be extremely difficult to prove unless a solicitor can testify that at the time of execution he fully explained to the mortgagor the nature of the protection given him by The Judicature Act.

The other approach was found in the judgment of Clinton J. Ford, J.A.: ${ }^{33}$

"It is quite clear to me on the facts that the defendants did not have any such intention; but, nevertheless, if the documents signed by them on a true interpretation effect such (implied waiver), they would be bound thereby."

From this it appears that the Court will hold the mortgagor to have waived the protection of The Judicature Act if the personal covenant signed by the mortgagor expressly provides that the mortgagee can sue the mortgagor personally. Perhaps the waiver provision ought expressly to refer to the protection given by The Judicature Act and to state that the mortgagor waives that protection. According to Clinton J. Ford, J.A., if such a provision is found

8slbid., at p. 112.

84Ibid., at pp. 112-113.

8oIbid., at p. 113. 
in the document, it will not be necessary for the mortgagee to prove actual knowledge by the mortgagor of the protection given him by The Judicature Act. $^{38}$

${ }^{36} \mathrm{~A}$ form of waiver provision now found in some mortgages in Alberta reads as follows: "And having been instructed as to the meaning of Section 34 (17) and (18) of the Judicature Act, Cap. 164 R.S.A. 1955, and being fully aware that under those terms the Mortgagee's remedy under this mortgage is restricted to the within land, I DO HEREBY WAIVE THE SAID PROVISIONS OF THE JUDICATURE ACT AND AMEND. MENTS THERETO and confer upon the Mortgagee the right to recover from me by action on the covenant for payment as herein contained, the principal, interest and other monies from time to time due under this mortgage. AND I DO FURTHER WAIVE the provisions of any Acts which may be enacted and in force from time to time in replacement of or in addition to the provisions of the said Sec. 34 (17) and (18) of the Judicature Act."

Similarly, in some Guarantee covenants given by strangers to the mortgage, the waiver provision reads as follows:

"HAVING been instructed as to the meaning of Section 34 (17) and (18) of the Judieature Act, being Chapter 164 of the Revised Statutes of Alberta 1955, as amended, and being fully aware that under and by virtue thereof the Mortgagee's remedy under this mortgage is restricted to the within land, I DO HEREBY WAIVE all righes and benefits that I may have under and by virtue of the said provisions of the Judieature Act as amended and agree that the Mortgagee shall have the right to recover from me personally, all losses, costs, charges, damages and expenses that it may suffer, incur or be put to and become liable for by reason of the non-payment of the said mortgage moneys, and incerest or any part thereof or of the non-performance of any of the terms, conditions and provisos in the said mortgage contained, and I FURTHER AGREE that my liability and obligation hereunder shall be satisfied only by the satisfaction of the covenants and conditions in the said mortgage contained by the Mortgagor to be performed." 